\title{
CAESAREAN VERUS VAGINAL DELIVERY IN THE MANAGEMENT OF ECLAMPSIA.
}

\author{
DR. RAHILA FARHAT \\ MBBS, MCPS, FCPS, \\ Gynaecologist, \\ Social Security Hospital Faisalabad
}

\author{
PROF. DR. MAHNAAZ ROOHI \\ MBBS, MRCOG, FRCOG, \\ Professor and Head of Gynae Department, \\ Allied Hospital/PMC Faisalabad
}

\begin{abstract}
Objective: To compare the results of vaginal delivery and caesarean section in the management of eclampsia in terms of maternal, fetal, morbidity and mortality. Study Design: This is a comparative study. Setting: It was carried in Gynae Unit I of Allied Hospital, Faisalabad, Period: From August 1999 till required sample was complete. Material and Methods: Hundred patients presenting to labour room with history of fits and hypertension were included in the study. Patients were divided into two groups. Group A included those patients under going L.S.C.S Group B included those undergoing vaginal delivery. Diagnosis was made on history examination and laboratory findings. Results: It was seen that maternal morbidity and mortality was low in patients undergoing vaginal delivery. There was no mortality in group B whereas in patients who had undergone L.S.C.S 6 expired. The need for ventilatory support was increased in group A (12 patients landed in ICU because of delayed recovery from anaesthesia). In group B no one needed ventilatory support. Those patients undergoing LSCS required more time to attain consciousness as compared to those undergoing vaginal delivery. Those undergoing LSCS required antihypertensive drugs for longer duration as compared to other group. The duration of hospital stay was decreased in patients of vaginal delivery. Conclusion: According to study carried out in Allied Hospital showed a decrease in maternal morbidity and mortality in patients undergoing vaginal delivery.
\end{abstract}

Keywords: Eclampsia, Vaginal Delivery, Caesarean Section.

\section{INTRODUCTION}

\section{HISTORICAL BACKGROUND}

Pre-eclampsia has been recognized as a clinical entity since the time of Hippocrates. Eclampsia is occurrence of grand mal seizures in a pregnant women known to have hypertension in late 2 nd trimester of pregnancy during labour or within 7 days after delivery not caused by other convulsive disorders. It is uncommon in developed countries and 20 times more common in developing countries.

Eclampsia, although first identified more than 150 years ago, its prime cause remains unknown. It has 
been thought to be a neurological, renal, hepatic and more recently placental disorder ${ }^{1}$.

Despite the reduction in incidence of severe disease eclampsia remains one of the causes of maternal mortality and morbidity in UK.

As far as the baby is concerned perinatal mortality and morbidity is related to placental insufficiency and complication of premature delivery. The level of maternal blood pressure is not a significant factor. A large number of factors predispose to the development of eclampsia.

Increased risk is seen in extremities of age. The protective effect of long term sperm exposure provides explanation for high frequency in teenage pregnancies $^{2}$. It is twice as common in primigravid women as in women having 2 nd or $3 \mathrm{rd}$ pregnancies $^{3}$. It is more common in low socioeconomic patients. Different races have different incidence.

Increased incidence in Muslim arabs, j'ews African American race is a risk factor ${ }^{4}$.

Mothers with twin pregnancies have 25.3\%. Increased incidence of developing eclampsia as compared to $3.4 \%$ in single one.

In rapidly growing mole there is $70 \%$ incidence of eclampsia. This is due to excessive trophoblastic activity. $50 \%$ of hydrops fetalis have eclampsia, compared with $0.6 \%$ in hemolytic disease without hydrops suggesting that eclampsia may be due to hyperplacentosis associated with hydrops. It is more in cold weather because of vasoconstriction.

Obesity is definite risk for developing pregnancy induced hypertension including eclampsia ${ }^{5}$. In Conde Agudelo and belizans study in a cohort of 878680 pregnancies the frequencies of pre eclampsia for lean women was $2.6 \%$ versus $10.1 \%$ in obese women ${ }^{6}$. Chronic hypertension is associated with increase in neonatal mortality and morbidity ${ }^{7}$.

There is increased in incidence of pre-eclampsia in women with pre-existing vascular disease.

Studies of women with known kidney disease have revealed that severe proteinuria in early pregnancy is a major risk for adverse neonatal outcome, whether or not blood pressure is controlled ${ }^{8}$. In long standing diabetes with vascular involvement there are increased chances of pre-eclampsia.

Cigarette smoking is associated with $30-40 \%$ decrease in the risk of pre-eclampsia'. These beneficial effect might be mediated by nicotine through inhibition of IL2 and tumour necrosis factor production by mononuclear cells.

Daughters of women with pre-eclampsia are 4 to 5 times likely to develop syndrome. An abnormal maternal and fetal interaction has been implicated cause of pre-eclampsia ${ }^{10}$. The incidence of preeclampsia among primigravid women with a family history of pre-eclampsia was three times that among primigravid women who had no such history. The fetal genotype is a combination of maternal and paternal components. Therefore contribution of paternal genes to fetus may be important in pathophysiology of pre-eclampsia and paternal genes have a key role inplacentation. The fact that it occurs more in 1st pregnancy or after a change of parents suggest that thee is an interaction of maternal antibodies and paternally derived fetal antigens ${ }^{10}$. In another study the daughters of women with pre-eclampsia had nearly twice as a high risk of having pre-eclampsia themselves during first pregnancy as did the daughters of women with no history of eclampsia ${ }^{11}$.

\section{PATIENTS AND METHODS}

A total of hundred patients presenting to labour 
room with history of fits and hypertension were included in study. Patients with other causes of fits like hyper glycemia epilepsy, uremia were excluded from study. The patients were nursed in left lateral position. Intermittent oxygen inhalation was given. Patient was catherized and intake and output chart maintained one hourly.

Injection valim $10 \mathrm{mg}$ intravenously diluted form given slowly. In the mean time obstetric assessment was done. Abdominal examination was done to assess the fundal hight, lie of baby and presenting part was evaluated.

Bishop score was assessed by vaginal examination. In the mean time all routine tests were sent. A routine analysis of urine and blood was done. Antihypertensive treatment was started. Vitals were monitored half hourly. The mode of delivery was decided after the patient had two hours fit free period. The patient undergoing LSCS were those with unripe cervix, fetal distress uncontrolled seizures, mal-presentation. Those patients who had good bishop score were augmented with artificial rupture of membranes and then depending upon the uterine contraction, if not adequate syntocinon infusion was started. Second stage was shortened by vaccum extraction, forceps delivery. In the third stage only syntocinon was given. A proforma was used to collect data was then analyzed.

\section{RESULTS}

\begin{tabular}{|c|c|c|}
\hline \multicolumn{2}{|c|}{ Table-l. Bishop score of patients presenting with eclampsia. } \\
\hline Bishop Score & $\begin{array}{c}\text { No. Of cases } \\
\text { delivered by LSCS }\end{array}$ & $\begin{array}{c}\text { Cases delivered by } \\
\text { N.V.D }\end{array}$ \\
\hline $0-3$ & 45 & 18 \\
\hline $4-6$ & 5 & 25 \\
\hline$>7$ & 0 & 7 \\
\hline
\end{tabular}

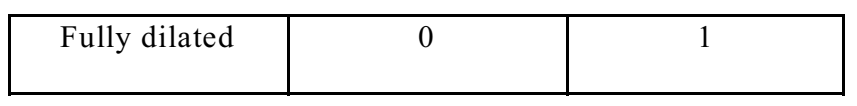

\begin{tabular}{|c|c|}
\hline \multicolumn{2}{|c|}{ Table-1l. Method used for induction. } \\
\hline Method & No. Of Cases \\
\hline ARM and syntocin & 29 \\
\hline PGE2 & 15 \\
\hline
\end{tabular}

$64 \%$ of patients delivered within 3-6 hours of induction.

In patients with vaginal delivery $58 \%$ achieved conscious level in 3-8 hours. Whereas those delivered by LSCS 56\% achieved conscious level in 25-30 hours

\begin{tabular}{|c|c|}
\hline \multicolumn{2}{|c|}{ Table-Ill. Induction Delivery Time } \\
\hline Time & No. Of Cases \\
\hline $3-6$ Hours & 32 \\
\hline 7-10 Hours & 11 \\
\hline $11-14$ Hours & 6 \\
\hline $15-18$ Hours & 1 \\
\hline
\end{tabular}

\begin{tabular}{|c|c|c|}
\hline \multicolumn{2}{|c|}{ Table-IV. Conscious Level Attained. } \\
\hline In Hours & $\begin{array}{c}\text { Cases Delivered By } \\
\text { LSCS }\end{array}$ & $\begin{array}{c}\text { Cases Delivered By } \\
\text { NVD }\end{array}$ \\
\hline $3-8$ Hours & 0 & 29 \\
\hline 9-1 4 Hours & 0 & 11 \\
\hline $15-20$ Hours & 8 & 4 \\
\hline $20-24$ Hours & 14 & 6 \\
\hline $25-30$ Hours & 28 & 0 \\
\hline
\end{tabular}




\begin{tabular}{|c|c|c|}
\hline \multicolumn{2}{|c|}{ Table-V. Duration of Hospital Stay. } \\
\hline Hospital Stay & Cases By LSCS & Cases By NVD \\
\hline 2-4 Days & 20 & 44 \\
\hline 5-7 Days & 25 & 5 \\
\hline > 10 Days & 5 & 1 \\
\hline
\end{tabular}

It is seen that patients delivering vaginally were discharged within 2-4 days whereas those undergoing LSCS $50 \%$ stayed in hospital for one week.

\begin{tabular}{|c|c|}
\hline \multicolumn{2}{|c|}{ Table-VI. Need for Ventilator } \\
\hline Ventilator Need & No. Of Cases \\
\hline LSCS & 11 ( $\begin{array}{c}\text { were used to delayed } \\
\text { recovery })\end{array}$ \\
\hline NV & 2 \\
\hline
\end{tabular}

In patients undergoing LSCS $22 \%$ patients required ventilatory support, whereas n group B only $4 \%$ required ventilatory support.

\begin{tabular}{|l|c|c|}
\hline \multicolumn{2}{|c|}{ Table-VII. Need for Anti Convulsants. } \\
\hline Anti Convulsants & By LSCS & BYNVD \\
\hline Need for Valium & 6 & 3 \\
\hline Need for Diuretics & 2 & 0 \\
\hline
\end{tabular}

\begin{tabular}{|c|c|c|}
\hline \multicolumn{2}{|c|}{$\begin{array}{c}\text { Table-VIII. Anti-Hypertensive Requirements in } \\
\text { Immediate Post Operative Period Anti-Hypertensive. }\end{array}$} \\
\hline Anti-Hypertensive & BY LSCS & BYNVD \\
\hline No anti-hypertensive req & 10 & 47 \\
\hline One drug required & 30 & 3 \\
\hline > one drug required & 10 & 0 \\
\hline
\end{tabular}

\section{DISCUSSION}

Pre-eclampsia is a hypertensive disorder of late pregnancy that resolves after delivery. It occurs in $10 \%$ of all pregnancies and is major cause of maternal and fetal morbidity and mortality ${ }^{12^{\prime} 13^{\prime} 14}$. It is caused by cerebral hypoxia from intense vasospasm. Ct scan shows cerebral odema from thrombosis and ischemia15. It is characterized by a marked increase in peripheral vascular resistence which in turn causes the increase in blood pressure.

Eclampsia is still a serious complication in un educated women who do not receive ante natal care $^{16}$. In our study $88 \%$ of the patients were not booked and had no ante natal care. Eclampsia is a major cause of maternal mortality and morbidity world wide ${ }^{17^{\prime} 18^{\prime} 19}$, despite the low incidence in countries with adequate provision of ante natal care and facilities for early hospitalization of pregnant women with hypertension ${ }^{18^{\prime} 1920}$. The needs to be easy quick system of referral from community into monitoring system. In our study $79 \%$ were not referred and only $21 \%$ of patients were referred to our unit.

Both early control and follow up of lab parameters and immediate delivery by LSCS if necessary may lead to reduction of maternal morbidity and mortality and to improvement of perinatal results ${ }^{21}$. The main stay of management are integrated antenatal care, access to monitoring services, stabilization of maternal condition and delivery of baby in way to benefit both mother and Child.

Antenatal care must provide easy access to monitoring services. The perinatal mortality rate for eclampsia in the series was relatively good for developing country, this may be due to early reason to LSCS.

The most common causes of maternal death were eclampsia 20.7\%, septic abortion 20.7\%, postpartum sepsis $10 \%$, obstructed labour $10.3 \%$, $\mathrm{APH}$ and pph $10.3 \%$. Other factors that are important in bringing about a significant reduction 
in maternal death include an improvement in knowledge attitudes and practices of community. Finally a national program on family health, education and improvement of socioeconomic status of women be implemented.

Although delivery removes the cause o eclampsia, the manifestation particularly hypertension may take weeks to resolve. Women require intense monitoring following delivery with attention to blood pressure fluid balance ${ }^{22}$.

Lack of antenatal care is responsible for high maternal mortality rate following eclampsia ${ }^{23} 24$. It has been seen from the study that patients undergoing vaginal delivery has low morbidity and mortality so one should try to deliver the patient of eclampsia vaginally if bishop is favorable. In many third world countries, HTN disorders of pregnancy are a major cause of maternal death and many studies have shown maternal mortality following eclampsia varies from $0-20 \%$. The survey shows that mortality from eclampsia is very common in young primigravida and elderly women of high parity, this is because of poor adjustment of these women to stress for pregnancy.

In UK number of maternal death from HTN has fallen steadily over past few years, however in other parts of the world the rates of morbidity and morality remain high and will continue until there is general improvement in maternity services.

\section{REFERENCES}

1. Roberts JM, Redman CWG. Pre eclampsia more than pregnancy induced hypertension. Lancet 1993, $341 ; 1447-1451$.

2. Martin JJ, Hermann U. Immunogenetosis; a new etiologic concept of essential EP. Gestosis, with special consideration of the premigravid. Am J Obstet Gynaecol 1977; 128: 489-493.

3. Trupin LS. Simon LP, Eskenazibb, change in paternity, a risk factor for pre-eclampsia in multi paras. Epidemiology 1996; 7: 240-244.

4. Haddad B, Barton JR, Living Stone JC, Chahine R, Sibai BM, Risk factors for adverse maternal outcome among women with help syndrome. Am J Gynaecol 2000 .

(AUG) 183(2); 444-8.

5. Martin JN, JR May WL, Rinehart BK, Martin RW, Magann EF, Increasing maternal weight; a risk factor for pre-eclampsia but apparently not for help syndrome. Southern Medical Journal 2000. 93(7): 686-91.

6. Conde-Agudelo A, Belizan JM. Risk factors for preeclampsia in a large cohort of Latin American and Caribbean women. Br J Obstet Gynaecol 2000; 107:75-83.

7. Siabi BM, Diagnosis and management of chronic hypertension in pregnancy. Obstet Gynaecol 1991; 78: 451-461.

8. Jungers P, Forget D, Henry Amar et al. Chronic kidney disease and pregnancy. Adv nephrol necks Hospital; 1986; 15: 103-141.

9. Marestsma GS, Donze GJ, Van Dijik AP, Tak CJ, Wilson JH, Zijlstra FJ. Nicotine inhibits the in vitro production of IL-2 and TNF \& by human mononuclear cells.

Immunopharmacology 1996; 35: 47-51.

10. Dekher GA, Sibai BM. Etiology and pathogenesis of pre-eclampsia; current concepts, Am J Obstet Gynaecol 1998; 179: 1359-1375.

11. Morgen I, Hogberg U, Winkvist A, Stendlund H, Familial occurance of pre-eclampsia. Epidemiology 1999; 10:518-22.

12. Daavey DA, Mac Gillivary I. The classicification and definition of the anti-hypertensive disorders of I pregnancy, Am J Obstet Gynaecol 1986; 1: 97-133.

13. Hypertensive disorders of pregnancy in; Cunningham FG, Mac Donald PC, Gant NF, Williams Obstetrics 18 th ed. Norwalk Conn; Appleton \& Lange. 1989; 653-94. i

14. Kaunitz AM, Hughes JM, Grimes DA, Smith JC, Rochat RW, Kafrissen ME, Causes of maternal mortality in the Uniter States. Obstet Gynaecol 1985; 


\section{5: 605-612.}

15. Mahmood K. Hypertension in pregancyeclampsia.Central African Journal of Medicine 1999; 45(9): 245-250.

16. Taner CE, Hakverdi AL, Erden AC, Ozelbay Kal U. Prevalence management and outcome in eclampsia. Int J Gynaecol. Obstet 1996; 53(1): 11-15.

17. Moodley J, Naicker RS; Eclampsia a method of management. S.A. FRI. Med J 1983; 63: 530-32.

18. Confidential enquiries into maternal deaths in the UK. HMSOLodon 1991.

19. Croowther CA, Management and pregnancy outcome in eclampsia at Harare Maternity Hospital. S. Afri Med J1998;31(6):307.
20. Moller B, Lindmark G. Eclampsia in Sweden 19761980. Acta Obstet Gynaecol Scand 1988; 65: 307.

21. Rath W Loos W, Kuuhrs W, Graef W. The important of early laboratory screening methods for maternal \& fetal outcome in cases of HELLP syndrome. Eur-JObstet-Gynaecol-Repord-Biol; July-Aug 1990.

22. Sliutz G, Schafer B, Obweegeser R, Jowa E, H ammerle A, Dadak C. Obstetric management of patients with HELLP syndrome. Z-Geburshilfe perinatal 1993 May-June; 197(3); 112-8.

23. Akinkugbe A CokerAA, Mortality in eclampsia.

24. A 10 years survey in pergnancy HTN ed J Bonnar, I, Mac Gillivery E, Symmonds 1980. MTP press Lancaster 475-480. 